\title{
A genome-wide scan of selective sweeps in two broiler chicken lines divergently selected for abdominal fat content
}

\author{
Hui Zhang ${ }^{1,2}$, Shou-Zhi Wang ${ }^{1,2}$, Zhi-Peng Wang ${ }^{1,2}$, Yang Da ${ }^{3}$, Ning Wang ${ }^{1,2}$, Xiao-Xiang Hu ${ }^{4}$, Yuan-Dan Zhang ${ }^{5}$, \\ Yu-Xiang Wang ${ }^{1,2}$, Li Leng ${ }^{1,2}$, Zhi-Quan Tang ${ }^{1,2}$ and Hui Li $i^{1,2^{*}}$
}

\begin{abstract}
Background: Genomic regions controlling abdominal fatness (AF) were studied in the Northeast Agricultural University broiler line divergently selected for AF. In this study, the chicken 60KSNP chip and extended haplotype homozygosity $(\mathrm{EHH})$ test were used to detect genome-wide signatures of AF.

Results: A total of 5357 and 5593 core regions were detected in the lean and fat lines, and 51 and 57 reached a significant level $(P<0.01)$, respectively. A number of genes in the significant core regions, including $R B 1, B B S 7, M A O A$, $M A O B, E H B P 1, \angle R P 2 B P, \angle R P 1 B, M Y O 7 A, M Y O 9 A$ and PRPSAP1, were detected. These genes may be important for AF deposition in chickens.

Conclusions: We provide a genome-wide map of selection signatures in the chicken genome, and make a contribution to the better understanding the mechanisms of selection for AF content in chickens. The selection for low AF in commercial breeding using this information will accelerate the breeding progress.
\end{abstract}

Keywords: Abdominal fat, Selection signature, Extended haplotype homozygosity (EHH)

\section{Background}

The linkage disequilibrium (LD) is important in livestock genetics for its key role in genomic selection [1] and detecting the causal mutations of economically important traits [2-6]. Based on the LD information, there are two main methods to detect genes underlying phenotypic variation, including one from phenotype to genome and another one from genome to phenotype. The first method is performed by targeting particular candidate genes or by quantitative trait loci (QTL) mapping and positional cloning of QTL. In the second method, patterns of LD in populations that are incompatible with the hypothesis of genetic neutrality are identified, and these patterns are selection signatures [7]. The aim of the second method is to identify artificial selections by statistically evaluating the genomic data [7].

\footnotetext{
* Correspondence: lihui@neau.edu.cn

${ }^{1}$ Key Laboratory of Chicken Genetics and Breeding, Ministry of Agriculture, Harbin 150030, P.R. China

${ }^{2}$ College of Animal Science and Technology, Northeast Agricultural University, Harbin 150030, P.R. China

Full list of author information is available at the end of the article
}

Allele frequencies underlying selection are expected to change. A neutral mutation will take many generations until the mutated allele reaches a high or low population frequency. In this case, the LD between the mutation and its neighboring loci will be degraded because of the recombination in every generation [8]. The frequency of a novel mutation will increase or decrease more rapidly than the neutral mutation because it is underlying artificial selection, so that the surrounding conserved haplotype was long $[9,10]$. This is the background of the extended haplotype homozygosity (EHH) statistic method used to detect selection signatures [11]. There are also many other methods to detect selective sweeps from DNA sequence data, including the Tajima's $D$ [12] and Fay and Wu's $H$-test [13] for selected mutations, measuring large allele-frequency differences among populations by $\mathrm{F}_{\mathrm{ST}}$ [14], and the integrated Haplotype Score (iHS) [15], which is an extension of the EHH statistic [11]. Among these methods, the EHH test is particularly useful $[7,11]$. The EHH test is used to detect artificial selections according to the characteristics of

\section{Biomed Central}


haplotypes within a single population, and do not require the genotype of the ancestor [7]. Furthermore, the $\mathrm{EHH}$ test is less sensitive to ascertainment bias than other approaches, so it was designed to work with SNP rather than sequencing data $[7,16]$.

The broilers used in this study were selected for eleven generations and genomic regions controlling AF deposition are expected to exhibit signatures of selective sweep. The aim of this study was to identify the selection signatures underlying the artificial selection for $\mathrm{AF}$ in chicken and to investigate the genes important for AF deposition.

\section{Methods}

\section{Ethics statement}

All animal work was conducted according to the guidelines for the care and use of experimental animals established by the Ministry of Science and Technology of the People's Republic of China (Approval number: 2006398) and approved by the Laboratory Animal Management Committee of Northeast Agricultural University.

\section{DNA samples and data preparation}

Broilers used in this study were from two Northeast Agricultural University broiler lines divergently selected for AF content (NEAUHLF). The two lines have been selected since 1996 using AF percentage (\%AFW or AFP) and plasma very low-density lipoprotein (VLDL) concentration as selection criteria [17]. The two lines were selected for 11 generations and the AFP changes over the 11 generations are shown in Figure 1. A total of 475 individuals from generation 11 of NEAUHLF were used in this study.

Genotyping was carried out using the Illumina chicken 60K SNP chip containing a total of 57636 SNPs. Markers were filtered to exclude loci with unknown positions, monomorphic loci and loci with a minor allele frequency $<0.05$.

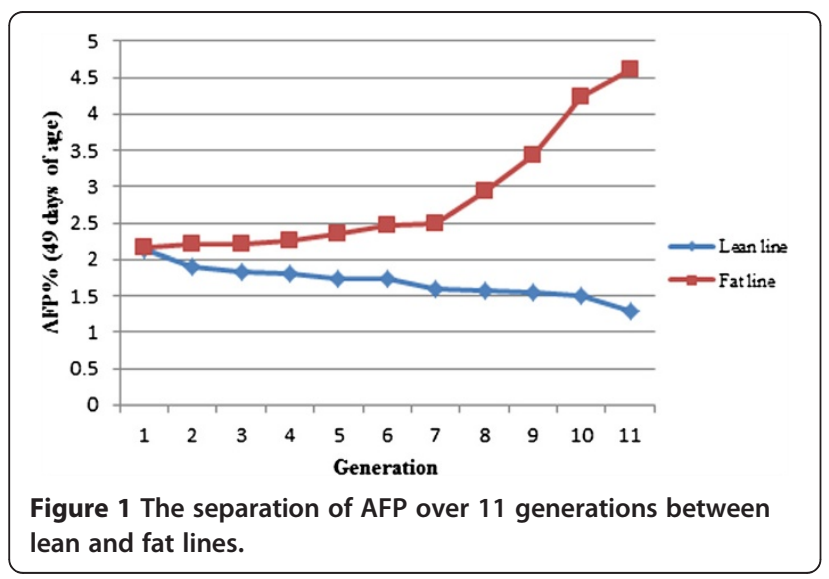

\section{The haplotype and LD analysis}

The fastPHASE [18] (http://depts.washington.edu/fphase/ download/) was used to reconstruct the haplotypes for every chromosome using the default parameters. The reconstructed haplotypes were inserted into HAPLOVIEW v4.1 [19] to estimate LD statistics based on pairwise $r^{2}$ and to construct the blocking pattern in the candidate regions of interest to enable selection signature analysis.

\section{The EHH test}

The "core region" was defined as the region in the genome characterized by the strong LD among SNPs involving a set of "core haplotypes" [7]. The Sweep v.1.1 (http:// www.soft82.com/get/download/windows/sweep/) was used to identify the core regions [11]. The algorithm defined a pair of SNPs to be in strong LD if the upper 95\% confidence bound of D' is between 0.70 and 0.98 [20]. The program was set to select core regions with at least two SNPs. EHH was defined as the probability that two randomly chosen haplotypes carrying the candidate core haplotype were homozygous for the entire interval spanning the core region to a given locus [11]. The EHH test [11] was based on one of the core haplotype vs. other haplotypes in the same position. The "Relative Extended Haplotype Homozygosity" (REHH) statistic corrects EHH for the variability in recombination rates [7]. It was computed by $\mathrm{EHH}_{\mathrm{t}} / E \bar{H} H$; with $E \bar{H} H$ defined as the decay of $\mathrm{EHH}$ on all other core haplotypes combined. The REHH value was used in the current study to determine the selection signatures. To determine the significance of REHH values, the haplotypes were ordered into 20 bins according to their frequencies [7]. The REHH values of each haplotype in a candidate region were compared with all equally frequent haplotypes and the $P$-values were obtained [11]. The significant selection signatures were defined as $P<0.01$.

\section{Results}

\section{Markers and core haplotypes}

A total of 43034 SNPs on 28 autosomes in chickens were included in the selection signature analysis (Table 1). These markers covered $950.68 \mathrm{Mb}$ of the genome, with an average of $22.09 \mathrm{~kb}$ between adjacent markers.

For the SNPs analyzed in this study, the average minor allele frequency was $0.29 \pm 0.13$. A summary of genomewide markers and core haplotype distribution in the data set is shown in Table 1. A total of 5357 and 5593 core regions spanning $549523.91 \mathrm{~kb}$ and $480784.79 \mathrm{~kb}$ of the genome, respectively, in the lean and fat lines were detected (Table 1). Mean core region length was estimated as $102.58 \pm 37.24 \mathrm{~kb}$ and $85.96 \pm 26.65 \mathrm{~kb}$, with a maximum of $2288.64 \mathrm{~kb}$ and $2191.34 \mathrm{~kb}$ in the lean and 
Table 1 Summary of genome-wide marker and core region (CR) distribution in the lean and fat lines

\begin{tabular}{|c|c|c|c|c|c|c|c|c|c|c|c|c|c|c|c|c|c|c|c|}
\hline \multirow[t]{2}{*}{ Chr } & \multirow[t]{2}{*}{$\begin{array}{l}\text { SNP } \\
(n)^{1}\end{array}$} & \multirow{2}{*}{$\begin{array}{l}\text { Chr } \\
\text { length } \\
\text { (Mbp) }\end{array}$} & \multirow{2}{*}{$\begin{array}{c}\text { Mean } \\
\text { distance } \\
\text { (kb) }\end{array}$} & \multicolumn{2}{|c|}{ No. CR (n) } & \multicolumn{2}{|c|}{$\begin{array}{l}\text { Mean CR length } \\
(\mathrm{kb})\end{array}$} & \multicolumn{2}{|c|}{$\begin{array}{l}\text { Coverage CR } \\
\text { length }^{2}(\mathrm{~kb})\end{array}$} & \multicolumn{2}{|c|}{$\begin{array}{l}\text { Max CR length } \\
\text { (kb) }\end{array}$} & \multicolumn{2}{|c|}{$\begin{array}{l}\text { CR length/Chr } \\
\text { length }^{3}\end{array}$} & \multicolumn{2}{|c|}{$\mathrm{CR} \mathrm{SNPs}^{4}$ (n) } & \multicolumn{2}{|c|}{ Max CR SNPs (n) } & \multicolumn{2}{|c|}{ CR SNPs/SNP } \\
\hline & & & & $\begin{array}{l}\text { Lean } \\
\text { line }\end{array}$ & $\begin{array}{l}\text { Fat } \\
\text { line }\end{array}$ & $\begin{array}{l}\text { Lean } \\
\text { line }\end{array}$ & $\begin{array}{l}\text { Fat } \\
\text { line }\end{array}$ & Lean line & Fat line & $\begin{array}{l}\text { Lean } \\
\text { line }\end{array}$ & $\begin{array}{l}\text { Fat } \\
\text { line }\end{array}$ & $\begin{array}{l}\text { Lean } \\
\text { line }\end{array}$ & $\begin{array}{l}\text { Fat } \\
\text { line }\end{array}$ & $\begin{array}{l}\text { Lean } \\
\text { line }\end{array}$ & $\begin{array}{l}\text { Fat } \\
\text { line }\end{array}$ & $\begin{array}{l}\text { Lean } \\
\text { line }\end{array}$ & $\begin{array}{l}\text { Fat } \\
\text { line }\end{array}$ & $\begin{array}{l}\text { Lean } \\
\text { line }\end{array}$ & $\begin{array}{l}\text { Fat } \\
\text { line }\end{array}$ \\
\hline 1 & 7135 & 200.95 & 28.16 & 881 & 920 & 125.59 & 114.92 & 110644.43 & 105728.03 & 2288.64 & 2191.34 & 0.55 & 0.53 & 3906 & 3716 & 19 & 19 & 0.55 & 0.52 \\
\hline 2 & 5290 & 154.46 & 29.20 & 639 & 695 & 149.62 & 108.91 & 95606.56 & 75690.16 & 2048.43 & 2042.96 & 0.62 & 0.49 & 3260 & 2628 & 19 & 19 & 0.62 & 0.50 \\
\hline 3 & 4081 & 113.65 & 27.85 & 517 & 533 & 121.58 & 108.97 & 62855.68 & 58081.43 & 863.98 & 735.27 & 0.55 & 0.51 & 2301 & 2107 & 19 & 19 & 0.56 & 0.52 \\
\hline 4 & 3313 & 94.16 & 28.42 & 411 & 428 & 137.96 & 108.07 & 56701.29 & 46255.07 & 2087.33 & 611.37 & 0.60 & 0.49 & 1992 & 1676 & 19 & 19 & 0.60 & 0.51 \\
\hline 5 & 2170 & 62.23 & 28.68 & 260 & 266 & 138.85 & 105.39 & 36101.29 & 28034.75 & 823.62 & 816.35 & 0.58 & 0.45 & 1282 & 1032 & 19 & 19 & 0.59 & 0.48 \\
\hline 6 & 1714 & 35.84 & 20.91 & 217 & 225 & 94.92 & 72.79 & 20598.01 & 16377.61 & 535.90 & 523.04 & 0.57 & 0.46 & 983 & 826 & 19 & 19 & 0.57 & 0.48 \\
\hline 7 & 1769 & 38.17 & 21.58 & 197 & 232 & 111.15 & 86.03 & 21897.27 & 19958.16 & 621.29 & 2163.72 & 0.57 & 0.52 & 1048 & 899 & 19 & 19 & 0.59 & 0.51 \\
\hline 8 & 1394 & 30.62 & 21.97 & 159 & 175 & 111.56 & 96.82 & 17738.07 & 16944.10 & 1914.74 & 1949.21 & 0.58 & 0.55 & 791 & 763 & 19 & 19 & 0.57 & 0.55 \\
\hline 9 & 1168 & 24.02 & 20.57 & 159 & 153 & 78.35 & 75.92 & 12457.00 & 11615.65 & 413.33 & 403.29 & 0.52 & 0.48 & 613 & 557 & 19 & 17 & 0.52 & 0.48 \\
\hline 10 & 1297 & 22.42 & 17.29 & 172 & 176 & 70.99 & 63.35 & 12210.13 & 11148.99 & 387.48 & 347.35 & 0.54 & 0.50 & 735 & 699 & 19 & 19 & 0.57 & 0.54 \\
\hline 11 & 1196 & 21.87 & 18.29 & 128 & 156 & 124.72 & 83.15 & 15964.06 & 12971.74 & 886.96 & 1093.97 & 0.73 & 0.59 & 871 & 706 & 19 & 19 & 0.73 & 0.59 \\
\hline 12 & 1324 & 20.45 & 15.44 & 169 & 184 & 71.34 & 51.16 & 12057.10 & 9412.86 & 352.96 & 369.92 & 0.59 & 0.46 & 809 & 633 & 19 & 19 & 0.61 & 0.48 \\
\hline 13 & 1128 & 18.32 & 16.24 & 144 & 141 & 75.86 & 75.09 & 10924.53 & 10584.67 & 373.56 & 373.56 & 0.60 & 0.58 & 695 & 656 & 19 & 19 & 0.62 & 0.58 \\
\hline 14 & 984 & 15.76 & 16.02 & 127 & 123 & 75.17 & 68.77 & 9546.48 & 8459.25 & 402.70 & 402.70 & 0.61 & 0.54 & 598 & 544 & 19 & 19 & 0.61 & 0.55 \\
\hline 15 & 1010 & 12.93 & 12.80 & 123 & 133 & 58.20 & 50.28 & 7158.60 & 6687.12 & 407.05 & 407.05 & 0.55 & 0.52 & 567 & 541 & 19 & 19 & 0.56 & 0.54 \\
\hline 16 & 12 & 0.17 & 13.87 & 3 & 1 & 41.85 & 67.25 & 125.54 & 67.25 & 64.36 & 67.25 & 0.74 & 0.40 & 9 & 3 & 4 & 3 & 0.75 & 0.25 \\
\hline 17 & 844 & 10.61 & 12.57 & 112 & 108 & 59.07 & 43.89 & 6616.05 & 4740.59 & 242.32 & 236.98 & 0.62 & 0.45 & 523 & 394 & 19 & 19 & 0.62 & 0.47 \\
\hline 18 & 845 & 10.89 & 12.88 & 112 & 121 & 48.74 & 45.96 & 5459.42 & 5561.31 & 317.30 & 317.30 & 0.50 & 0.51 & 431 & 431 & 12 & 19 & 0.51 & 0.51 \\
\hline 19 & 804 & 9.89 & 12.31 & 117 & 110 & 36.01 & 48.41 & 4212.67 & 5325.00 & 406.27 & 371.08 & 0.43 & 0.54 & 353 & 421 & 14 & 19 & 0.44 & 0.52 \\
\hline 20 & 1460 & 13.92 & 9.53 & 184 & 181 & 45.89 & 46.33 & 8442.96 & 8386.18 & 273.60 & 270.67 & 0.61 & 0.60 & 904 & 888 & 19 & 19 & 0.62 & 0.61 \\
\hline 21 & 726 & 6.88 & 9.47 & 81 & 90 & 47.74 & 35.17 & 3867.13 & 3165.72 & 211.67 & 196.05 & 0.56 & 0.46 & 432 & 354 & 19 & 18 & 0.60 & 0.49 \\
\hline 22 & 295 & 3.89 & 13.19 & 36 & 30 & 71.16 & 79.29 & 2561.59 & 2378.83 & 267.88 & 289.01 & 0.66 & 0.61 & 193 & 182 & 19 & 19 & 0.65 & 0.62 \\
\hline 23 & 577 & 6.02 & 10.44 & 81 & 80 & 37.13 & 31.74 & 3007.73 & 2539.51 & 239.20 & 239.20 & 0.50 & 0.42 & 307 & 272 & 19 & 19 & 0.53 & 0.47 \\
\hline 24 & 676 & 6.23 & 9.22 & 87 & 91 & 40.77 & 32.96 & 3546.91 & 2999.26 & 133.00 & 212.48 & 0.57 & 0.48 & 387 & 339 & 13 & 19 & 0.57 & 0.50 \\
\hline 25 & 170 & 2.02 & 11.86 & 23 & 18 & 34.97 & 32.38 & 804.26 & 582.82 & 82.74 & 72.39 & 0.40 & 0.29 & 99 & 68 & 12 & 10 & 0.58 & 0.40 \\
\hline 26 & 617 & 5.03 & 8.16 & 81 & 85 & 34.55 & 59.60 & 2798.60 & 2515.94 & 246.20 & 278.91 & 0.56 & 0.50 & 345 & 312 & 19 & 19 & 0.56 & 0.51 \\
\hline 27 & 472 & 4.84 & 10.25 & 60 & 59 & 46.66 & 40.46 & 2799.62 & 2387.38 & 384.65 & 482.24 & 0.58 & 0.49 & 299 & 215 & 19 & 19 & 0.63 & 0.46 \\
\hline 28 & 563 & 4.46 & 7.92 & 77 & 79 & 36.64 & 27.66 & 2820.93 & 2185.41 & 520.13 & 172.85 & 0.63 & 0.49 & 336 & 318 & 19 & 19 & 0.60 & 0.56 \\
\hline Total & 43034 & 950.68 & 22.09 & 5357 & 5593 & 102.58 & 85.96 & 549523.91 & 480784.79 & 2288.64 & 2191.34 & 0.58 & 0.51 & 25069 & 22180 & 19 & 19 & 0.58 & 0.52 \\
\hline
\end{tabular}

${ }^{1}$ The number of SNPs.

${ }^{2}$ Total length covered by core regions.

${ }^{3}$ The proportion of total core region lengths on chromosome length.

${ }^{4}$ Number of SNPs in core regions.

${ }^{5}$ The proportion of total number of SNPs in core regions on number of SNPs used. 


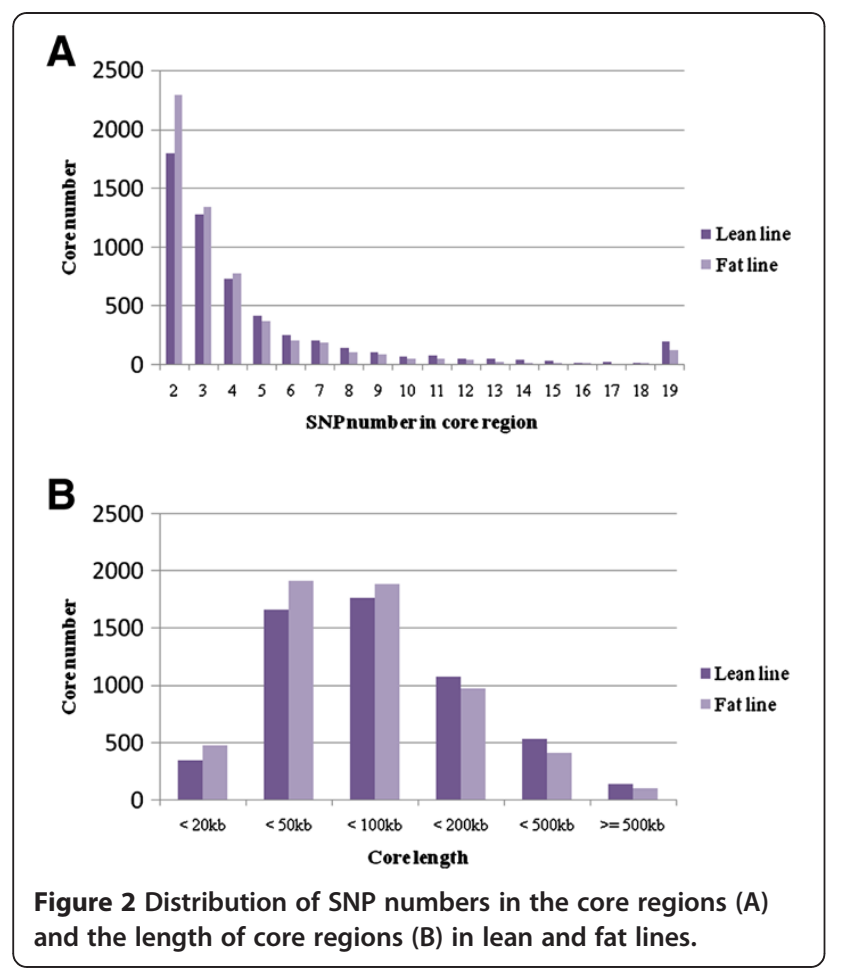

fat lines, respectively (Table 1). Chromosome 1 was the largest chromosome in chickens, and it had the largest haplotypic structures in the genome, which covered $110644.43 \mathrm{~kb}$ and $105728.03 \mathrm{~kb}$ in the lean and fat lines, respectively. For each chromosome, the proportion of length covered by core regions vs. total length, as well as the number of SNPs forming core regions vs. the total number of SNPs, are shown in Table 1. The distribution of the size of core regions is shown in Figure 2. Overall, 25069 and 22180 SNPs in the lean and fat lines, respectively, participated in forming core regions, with a range of 2 to 19 SNPs per core.

\section{Whole genome selection signatures}

For all 5357 and 5593 core regions in the lean and fat lines, respectively, a total of 44822 and $46775 \mathrm{EHH}$ tests, with an average of 8.37 and 8.36 tests per core region, were calculated. To find outlying core haplotypes, we calculated REHH at $1 \mathrm{Mb}$ distances both on the upstream and downstream sides. Figure 3 shows the distribution of REHH values vs. haplotype frequencies in the lean and fat lines, respectively. Corresponding $P$-values are indicated by different colored symbols. The $-\log _{10}$ of the $P$-values associated with REHH against the chromosomal position was plotted to visualize the chromosomal distribution of outlying core haplotypes with frequency $<25 \%$ (Figure 4). The results indicated that these selection signals were not uniformly distributed across all chromosomes, with a substantial overrepresentation on chromosomes 1, 2, 3 and 4.

The genome-wide statistics of the selection signature test, including the number of tests and outlying core haplotypes for each chromosome, are presented in Table 2. Of 16677 and 18346 tests on core haplotypes with frequency $\geq 0.25$, there were 51 and 57 tests with $P<0.01$ in the lean and fat lines, respectively. There were 153 and 251 tests with $P<0.05$ in the lean and fat lines, respectively.

The conformity of the distribution of Tukey's outliers was examined, with outlying core haplotypes defined at the threshold level of 0.01 . Figure 5 displays box plots of the distribution of $-\log 10$ ( $P$-values) within each bin of core haplotype frequency. The results indicated that the
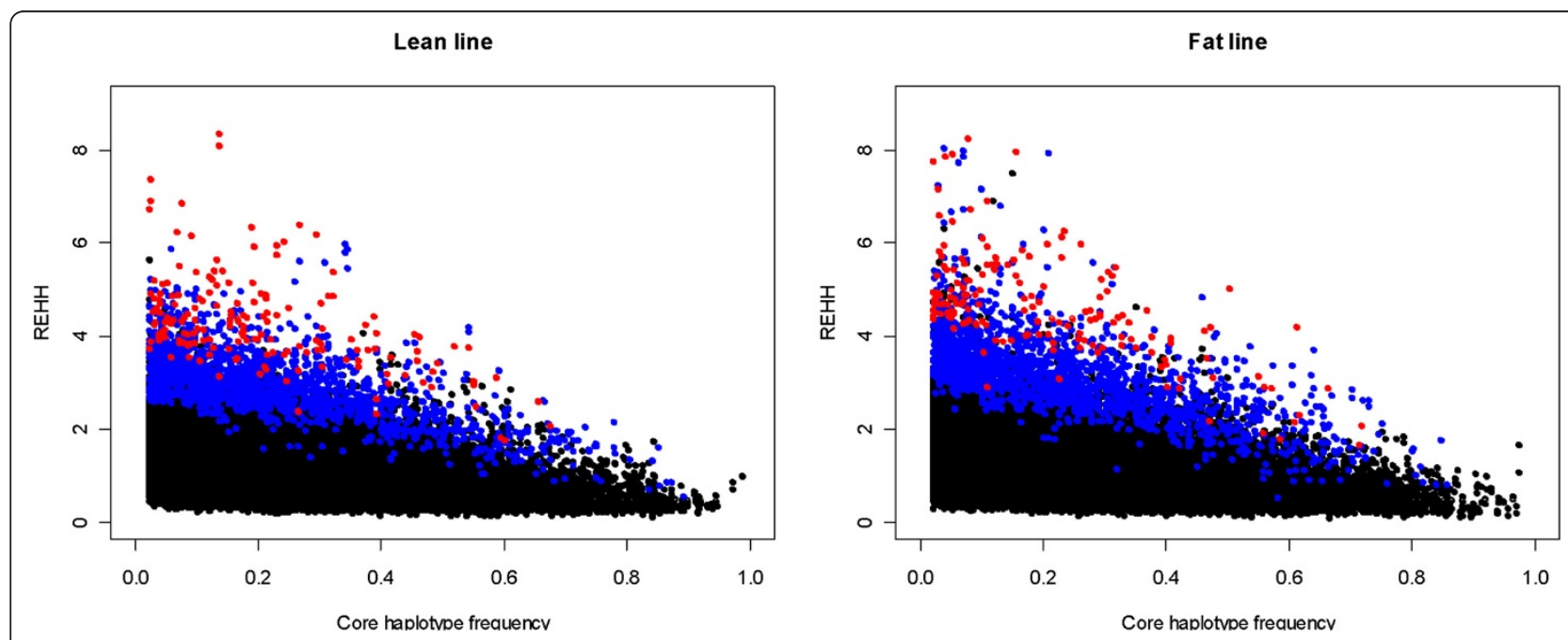

Figure 3 Distribution of REHH vs. core haplotype frequencies in the lean and fat lines. Core haplotypes with P-values lower than 0.05 and 0.01 are presented in blue and red, respectively. 


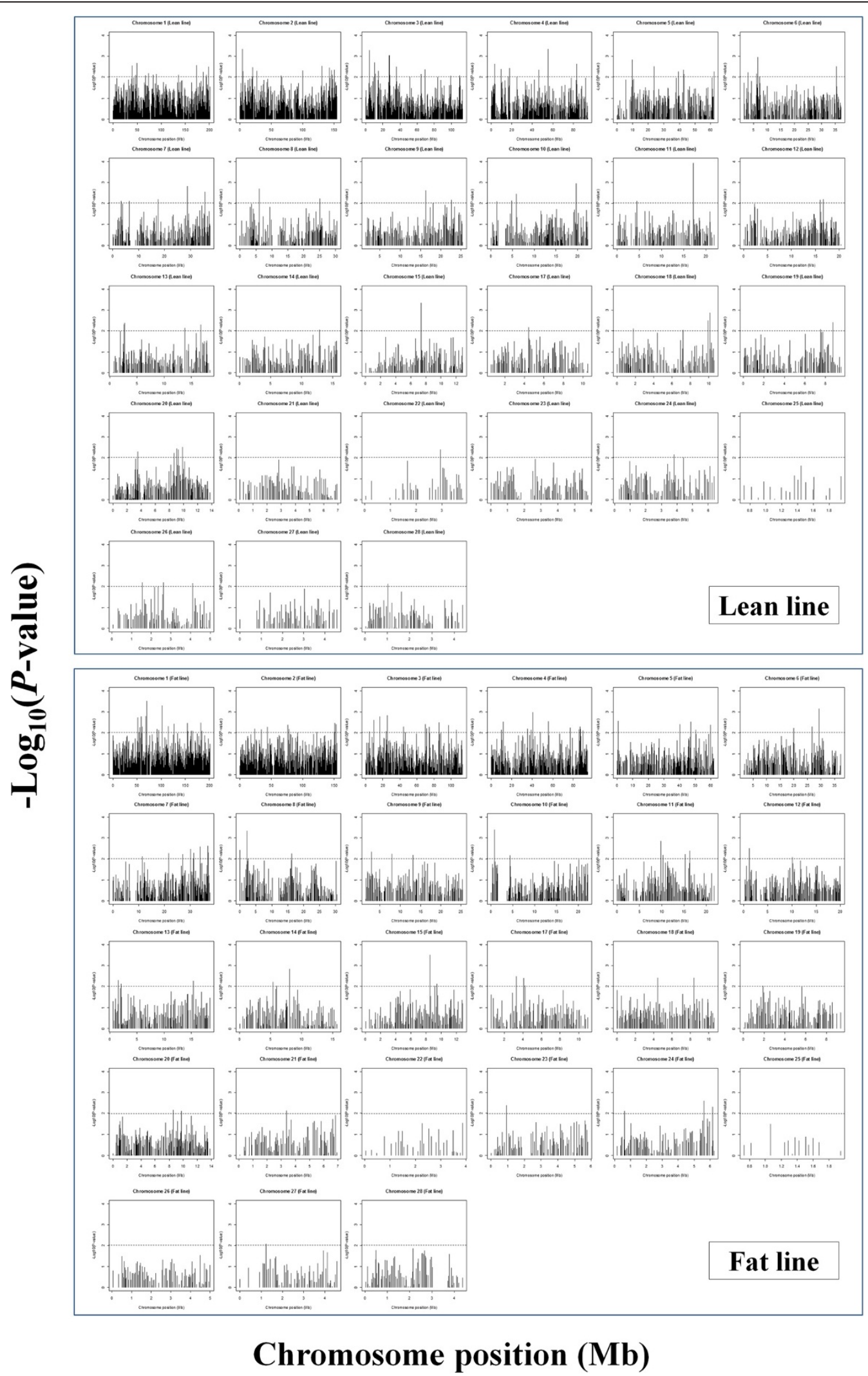

Figure 4 Genome-wide map of $P$-values for core haplotypes with frequency $>0.25$ in lean and fat lines, respectively. Dashed lines display the threshold level of 0.01 . 
Table 2 The number of tests on core haplotypes (CH) (both sides) with frequency $\geq 0.25$ and $P$-values of REHH test

\begin{tabular}{|c|c|c|c|c|c|c|}
\hline \multirow[t]{2}{*}{ Chr } & \multicolumn{3}{|c|}{ Lean line } & \multicolumn{3}{|c|}{ Fat line } \\
\hline & Test on $\mathrm{CH}$ & $P$-value $<0.05$ & $P$-value $<0.01$ & Test on $\mathrm{CH}$ & $P$-value $<0.05$ & $P$-value $<0.01$ \\
\hline 1 & 2806 & 113 & 4 & 3063 & 138 & 12 \\
\hline 2 & 2009 & 105 & 8 & 2271 & 104 & 3 \\
\hline 3 & 1654 & 79 & 10 & 1705 & 74 & 8 \\
\hline 4 & 1273 & 58 & 6 & 1371 & 66 & 5 \\
\hline 5 & 844 & 34 & 3 & 883 & 36 & 4 \\
\hline 6 & 699 & 25 & 2 & 757 & 31 & 2 \\
\hline 7 & 638 & 29 & 2 & 770 & 31 & 5 \\
\hline 8 & 464 & 16 & 1 & 574 & 33 & 2 \\
\hline 9 & 516 & 20 & 1 & 564 & 19 & 1 \\
\hline 10 & 540 & 23 & 2 & 582 & 27 & 1 \\
\hline 11 & 397 & 15 & 1 & 534 & 20 & 2 \\
\hline 12 & 503 & 14 & 0 & 619 & 20 & 1 \\
\hline 13 & 447 & 19 & 3 & 474 & 22 & 1 \\
\hline 14 & 379 & 14 & 0 & 418 & 16 & 1 \\
\hline 15 & 329 & 12 & 1 & 420 & 18 & 2 \\
\hline 17 & 350 & 16 & 0 & 348 & 14 & 2 \\
\hline 18 & 354 & 12 & 2 & 432 & 13 & 2 \\
\hline 19 & 334 & 12 & 1 & 338 & 13 & 0 \\
\hline 20 & 561 & 28 & 3 & 566 & 19 & 0 \\
\hline 21 & 255 & 6 & 0 & 304 & 11 & 0 \\
\hline 22 & 105 & 5 & 1 & 85 & 2 & 0 \\
\hline 23 & 258 & 11 & 0 & 245 & 12 & 1 \\
\hline 24 & 287 & 9 & 0 & 308 & 12 & 2 \\
\hline 25 & 46 & 1 & 0 & 36 & 1 & 0 \\
\hline 26 & 231 & 11 & 0 & 253 & 4 & 0 \\
\hline 27 & 181 & 8 & 0 & 184 & 7 & 0 \\
\hline 28 & 217 & 5 & 0 & 242 & 14 & 0 \\
\hline Total & 16,677 & 700 & 51 & 18,346 & 777 & 57 \\
\hline
\end{tabular}
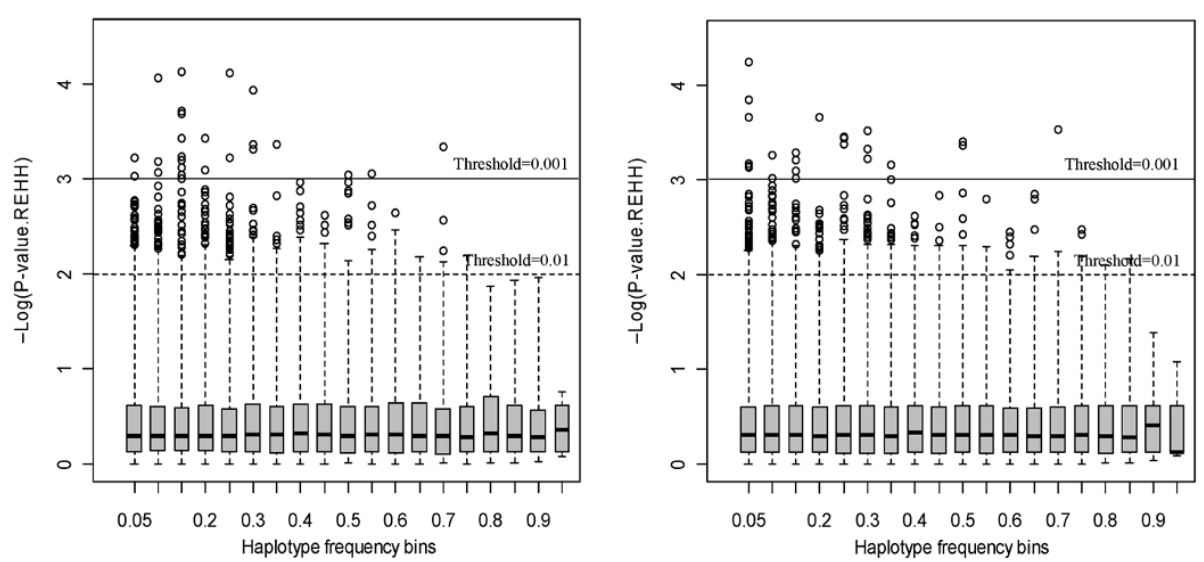

Figure 5 Box plot of the distribution of $P$-values in core haplotype frequency bins in the lean (left) and fat (right) lines. The dashed and continuous lines indicated the threshold $P$-values of 0.01 and 0.001 , respectively. 
Table 3 Statistics summary for core haplotypes with $P<0.01$ after the relative extended haplotype homozygosity (REHH) test

\begin{tabular}{|c|c|c|c|c|c|c|}
\hline \multicolumn{7}{|c|}{ Lean line } \\
\hline Chr & Core position & Hap Freq & $\mathrm{EHH}$ & REHH $^{1}$ & REHH $P$-value ${ }^{1}$ & Genes \\
\hline 1 & $39360501-39455853$ & 0.46 & 0.98 & 3.99 & 0.0027 & / \\
\hline 1 & $49926970-49964278$ & 0.30 & 0.97 & 4.18 & 0.0021 & C12orf69, WBP11, H2A4, H2B1, H4, H32, H2B8 \\
\hline 1 & 173098805-173190831 & 0.37 & 0.99 & 4.25 & 0.0027 & RB1, LPAR6, O57531, RCBTB2 \\
\hline 1 & 198071099-198113519 & 0.55 & 0.80 & 3.03 & 0.0031 & GDPD4, MYO7A \\
\hline 2 & 3631683-3739002 & 0.32 & 0.70 & 4.88 & 0.0004 & Q5ZK34 \\
\hline 2 & $19934135-20028093$ & 0.30 & 0.97 & 3.88 & 0.0035 & RSU1 \\
\hline 2 & $26912546-26974875$ & 0.28 & 1.00 & 3.65 & 0.0050 & I \\
\hline 2 & 99818321-100051643 & 0.41 & 1.00 & 3.00 & 0.0047 & GNAL, NRGN \\
\hline 2 & $131104507-131150076$ & 0.48 & 0.98 & 3.24 & 0.0029 & Q6VOPO, INTS8, F1P3N8 \\
\hline 2 & $143016981-143059231$ & 0.36 & 0.97 & 3.46 & 0.0034 & I \\
\hline 2 & $145836411-145908271$ & 0.30 & 1.00 & 3.72 & 0.0045 & / \\
\hline 2 & $150489129-150540434$ & 0.34 & 1.00 & 3.51 & 0.0044 & 1 \\
\hline 3 & 3794973-3861882 & 0.30 & 0.79 & 4.72 & 0.0005 & C20orf26, CRNKL1 \\
\hline 3 & 3794973-3861882 & 0.30 & 0.82 & 3.85 & 0.0020 & C20orf26, CRNKL1 \\
\hline 3 & 10257926-10454969 & 0.55 & 0.49 & 2.49 & 0.0019 & F1NRN6 \\
\hline 3 & 14895290-14957057 & 0.44 & 0.72 & 3.16 & 0.0048 & PLCB4 \\
\hline 3 & 26957549-26996618 & 0.46 & 0.80 & 3.69 & 0.0009 & 1 \\
\hline 3 & 26957549-26996618 & 0.46 & 0.83 & 3.47 & 0.0013 & / \\
\hline 3 & $27303800-27335510$ & 0.52 & 0.92 & 3.78 & 0.0009 & SRBD1 \\
\hline 3 & 27382993-27430067 & 0.54 & 0.84 & 3.77 & 0.0009 & SRBD1 \\
\hline 3 & $35555718-35610466$ & 0.47 & 0.66 & 3.02 & 0.0031 & E1C4G2 \\
\hline 3 & $68936320-69076223$ & 0.27 & 0.98 & 3.79 & 0.0041 & RPF2, GTF3C6, Q5F484, CDK19 \\
\hline 4 & 3522359-3551494 & 0.59 & 0.54 & 3.10 & 0.0023 & MBNL3 \\
\hline 4 & $9568761-9604871$ & 0.55 & 1.00 & 2.95 & 0.0040 & / \\
\hline 4 & 17765695-17819334 & 0.41 & 1.00 & 3.56 & 0.0037 & F1NEF4, HMGB3 \\
\hline 4 & $46149116-46190279$ & 0.36 & 0.99 & 3.35 & 0.0044 & EREG, Q645M5 \\
\hline 4 & $55424480-55472209$ & 0.66 & 0.9 & 2.60 & 0.0005 & $\operatorname{TRPC} 3, \mathrm{BBS7}$ \\
\hline 4 & $83051637-83117974$ & 0.39 & 0.87 & 3.72 & 0.0022 & I \\
\hline 5 & 9740941-9828144 & 0.49 & 1.00 & 3.42 & 0.0014 & IF4G2, CTR9, MRVII \\
\hline 5 & $23825115-23872187$ & 0.41 & 0.78 & 3.19 & 0.0030 & 093582 \\
\hline 5 & $42592517-42679460$ & 0.30 & 1.00 & 3.70 & 0.0044 & 1 \\
\hline 6 & 6546601-6626145 & 0.39 & 1.00 & 4.42 & 0.0011 & I \\
\hline 6 & $35354459-35390346$ & 0.38 & 0.99 & 3.72 & 0.0030 & PTPRE \\
\hline 7 & 28869664-28906344 & 0.31 & 1.00 & 4.88 & 0.0015 & MYLK \\
\hline 7 & $35674098-35715122$ & 0.67 & 0.48 & 2.09 & 0.0027 & \\
\hline 8 & 6107407-6172105 & 0.36 & 0.63 & 3.72 & 0.0020 & IER5, KIAA1614, XPR1 \\
\hline 9 & $16264832-16366749$ & 0.45 & 0.97 & 4.04 & 0.0024 & PSMD1, ARMC9, B3GNT7 \\
\hline 10 & 5831963-5856349 & 0.59 & 0.97 & 1.83 & 0.0034 & I \\
\hline 10 & 19717086-19745274 & 0.48 & 1.00 & 2.90 & 0.0011 & CHSY1 \\
\hline 11 & 17094961-17160195 & 0.30 & 0.63 & 3.35 & 0.0001 & BCDO1, GAN \\
\hline 13 & 2628777-2664596 & 0.35 & 1.00 & 3.94 & 0.0048 & Q5ZHQ9 \\
\hline 13 & $2726706-2746894$ & 0.39 & 0.79 & 4.06 & 0.0041 & I \\
\hline 13 & $16758621-16783127$ & 0.26 & 0.69 & 3.26 & 0.0050 & FSTL4 \\
\hline 15 & 7345639-7377799 & 0.26 & 0.54 & 2.38 & 0.0004 & SEZ6L, ASPHD2, HPS4 \\
\hline 18 & $9949736-10015444$ & 0.39 & 1.00 & 2.34 & 0.0031 & SPAG9 \\
\hline
\end{tabular}


Table 3 Statistics summary for core haplotypes with $P<0.01$ after the relative extended haplotype homozygosity (REHH) test (Continued)

\begin{tabular}{|c|c|c|c|c|c|c|}
\hline 18 & $10117401-10135964$ & 0.39 & 1.00 & 2.64 & 0.0013 & F1NM51 \\
\hline 19 & 8727596-8786448 & 0.60 & 0.55 & 1.77 & 0.0038 & MSII \\
\hline 20 & $9090808-9113453$ & 0.29 & 0.95 & 6.18 & 0.0036 & MYT1 \\
\hline 20 & $9246245-9278998$ & 0.32 & 0.80 & 5.39 & 0.0040 & E1C8MO \\
\hline 20 & 9879361-9899719 & 0.27 & 0.96 & 6.40 & 0.0030 & CSK21 \\
\hline 22 & $2952274-3002268$ & 0.29 & 0.29 & 3.93 & 0.0039 & / \\
\hline \multicolumn{7}{|c|}{ Fat line } \\
\hline 1 & $51248496-51279543$ & 0.33 & 0.81 & 4.45 & 0.0018 & TCF2O \\
\hline 1 & $58120009-58215364$ & 0.55 & 0.99 & 3.15 & 0.0016 & Q8UVD4 \\
\hline 1 & $60171076-60254771$ & 0.46 & 1.00 & 4.12 & 0.0049 & I \\
\hline 1 & $67763862-67830818$ & 0.26 & 0.96 & 4.06 & 0.0026 & I \\
\hline 1 & $68213617-68257241$ & 0.61 & 0.94 & 4.21 & 0.0016 & $50 \times 5$ \\
\hline 1 & 69634186-69686357 & 0.66 & 0.99 & 2.89 & 0.0003 & / \\
\hline 1 & $101535615-101635667$ & 0.29 & 1.00 & 5.24 & 0.0005 & SAMSN1 \\
\hline 1 & $114789487-114875623$ & 0.29 & 0.99 & 3.66 & 0.0048 & $M A O B, M A O A$ \\
\hline 1 & $125909995-126011984$ & 0.35 & 1.00 & 3.77 & 0.0036 & E1BTB5 \\
\hline 1 & $154665510-154752965$ & 0.72 & 0.89 & 2.09 & 0.0034 & l \\
\hline 1 & $181800227-181883545$ & 0.33 & 0.99 & 4.00 & 0.0033 & A1XGV6 \\
\hline 1 & $181800227-181883545$ & 0.33 & 1.00 & 3.81 & 0.0043 & A1XGV6 \\
\hline 2 & $76768841-76854523$ & 0.31 & 1.00 & 4.30 & 0.0041 & / \\
\hline 2 & $151203953-151251059$ & 0.62 & 0.82 & 2.32 & 0.0033 & TRAPPC9 \\
\hline 2 & $153117092-153143883$ & 0.71 & 0.77 & 1.68 & 0.0038 & / \\
\hline 3 & $9177907-9222825$ & 0.38 & 0.95 & 4.00 & 0.0024 & EHBP1 \\
\hline 3 & $9177907-9222825$ & 0.38 & 0.90 & 3.66 & 0.0039 & EHBP1 \\
\hline 3 & $16143474-16194865$ & 0.30 & 0.98 & 4.98 & 0.0016 & I \\
\hline 3 & 24945839-24986772 & 0.61 & 0.70 & 2.15 & 0.0014 & / \\
\hline 3 & $44265116-44311493$ & 0.40 & 0.99 & 3.50 & 0.0050 & UNC93A \\
\hline 3 & 69863850-69906698 & 0.34 & 1.00 & 4.29 & 0.0038 & / \\
\hline 3 & $85874137-85931473$ & 0.41 & 1.00 & 3.97 & 0.0031 & LMBRD1 \\
\hline 3 & $97227680-97337906$ & 0.28 & 0.99 & 3.81 & 0.0042 & / \\
\hline 4 & $11582141-11642538$ & 0.27 & 0.96 & 4.53 & 0.0029 & I \\
\hline 4 & $40653593-40713404$ & 0.32 & 0.93 & 4.40 & 0.0010 & C4orf20, LRP2BP, SNX25 \\
\hline 4 & $55950677-55991394$ & 0.28 & 0.99 & 4.55 & 0.0028 & l \\
\hline 4 & $55950677-55991394$ & 0.28 & 1.00 & 4.36 & 0.0036 & I \\
\hline 4 & $86719441-86754976$ & 0.57 & 0.75 & 2.88 & 0.0048 & / \\
\hline 5 & $556571-628531$ & 0.25 & 0.67 & 4.37 & 0.0026 & F1NYX6, PLCB2, BUB1B, PAK6 \\
\hline 5 & $40239840-40261525$ & 0.29 & 0.97 & 4.48 & 0.0038 & VSX2, F1N9P5 \\
\hline 5 & $47240577-47282933$ & 0.40 & 0.95 & 2.91 & 0.0029 & RIN3, LGMN \\
\hline 5 & $59811459-59880511$ & 0.39 & 0.66 & 3.36 & 0.0041 & 1 \\
\hline 6 & $26756202-26793956$ & 0.34 & 0.98 & 3.94 & 0.0049 & / \\
\hline 6 & 29341938-29401207 & 0.32 & 0.97 & 5.50 & 0.0007 & $A B L I M 1$ \\
\hline 7 & $30090927-30155133$ & 0.30 & 0.88 & 3.77 & 0.0033 & F1NF72 \\
\hline 7 & $31374271-31418061$ & 0.42 & 1.00 & 2.88 & 0.0049 & LYPD1, NCKAP5 \\
\hline 7 & $33795201-33904515$ & 0.47 & 1.00 & 2.20 & 0.0025 & $L R P 1 B$ \\
\hline 7 & $36818722-36875768$ & 0.26 & 0.99 & 3.95 & 0.0024 & Q9DEH4 \\
\hline 7 & $37031922-37124566$ & 0.56 & 1.00 & 2.92 & 0.0047 & STAM2, FMNL2 \\
\hline 8 & $5597-492518$ & 0.56 & 0.99 & 1.94 & 0.0036 & F1NF53 \\
\hline
\end{tabular}


Table 3 Statistics summary for core haplotypes with $P<0.01$ after the relative extended haplotype homozygosity (REHH) test (Continued)

\begin{tabular}{lcclllc}
\hline 8 & $2178258-2252969$ & 0.47 & 0.92 & 4.20 & 0.0004 & NEK7 \\
\hline 9 & $2952291-3007034$ & 0.41 & 0.71 & 3.85 & 0.0044 & $/$ \\
\hline 10 & $763998-831991$ & 0.50 & 0.78 & 5.04 & 0.0004 & MYO9A, F1P0M4 \\
\hline 11 & $9804894-9826761$ & 0.47 & 0.52 & 3.11 & 0.0014 & $/$ \\
\hline 11 & $16253047-16303345$ & 0.58 & 0.35 & 1.80 & 0.0040 & $/$ \\
\hline 12 & $1157199-1170169$ & 0.37 & 0.63 & 4.57 & 0.0030 & $/$ \\
\hline 14 & $1533552-1640154$ & 0.40 & 1.00 & 3.41 & 0.0049 & SRA1, APBB3, F1NH59 \\
\hline 15 & $8048059-8173629$ & 0.42 & 0.86 & 3.09 & 0.0015 & $/$ \\
\hline 15 & $8495796-8543001$ & 0.29 & 1.00 & 4.86 & 0.0003 & TBX6, CRKL, KLHL22 \\
\hline 17 & $3495796-8543001$ & 0.29 & 0.99 & 4.43 & 0.0006 & TBX6, CRKL, KLHL22 \\
\hline 17 & $4062173-4087131$ & 0.26 & 0.94 & 3.77 & 0.0033 & C4PCF3 \\
\hline 18 & $4433126-4445816$ & 0.26 & 0.79 & 5.99 & 0.0040 & PRPSAP1 \\
\hline 18 & $8365846-8400245$ & 0.47 & 0.80 & 3.53 & 0.0038 & $/$ \\
\hline 23 & $935267-970086$ & 0.31 & 0.91 & 5.40 & 0.0040 & EDN2 \\
\hline 24 & $5613517-5633477$ & 0.28 & 0.86 & 4.38 & 0.0024 & ZW10, F1NC10 \\
\hline 24 & $6145308-6158962$ & 0.31 & 0.80 & 5.30 & 0.0047 & $/$
\end{tabular}

${ }^{1} \mathrm{REHH}$ and $P$-values are presented for upstream and downstream sides from each core haplotype, respectively.

extreme outliers appear in the small haplotype frequencies bins.

\section{Mapping selection signatures to genes}

A summary of statistics for 51 and 57 positively selected core regions with $P<0.01$ of the $\mathrm{REHH}$ tests in the lean and fat lines, respectively, is presented in Table 3. Corresponding genes were identified by aligning the core positions with the chicken genome sequence (Table 3). The full genes names were from Ensembl online (http:// www.ensembl.org/index.html). A total of 66 and 46 genes in the core regions were detected in the lean and fat lines, respectively, including $R B 1$ (retinoblastoma 1), BBS7 (Bardet-Biedl syndrome 7), MAOA (monoamine oxidase A), $M A O B$ (monoamine oxidase B), EHBP1 (EH domain binding protein 1), LRP2BP (LRP2 binding protein), $L R P 1 B$ (low-density lipoprotein receptor-related protein 1B), MYO7A (myosin VIIA), MYO9A (myosin IXA) and PRPSAP1 (phosphoribosyl pyrophosphate synthetase-associated protein 1). The haplotype analysis of these genes revealed that the haplotype frequencies were significantly different $(P<0.01)$ between the two lines (Table 4).

\section{Mapping selection signatures to QTLs}

The chicken QTL database available online (http:// www.animalgenome.org/cgi-bin/QTLdb/GG/index) was explored to identify any overlapping of the core regions with significant $\mathrm{REHH} P$-values $(P<0.01)$ and published QTLs in chickens. The approximate positions of the overlapping QTLs for each core region are listed in Table 5. There were many overlaps between the core regions with significant $\mathrm{REHH} P$-values $(P<0.01)$ and published QTLs for AF content in chickens.

\section{Discussion}

Selective sweep is used to detect genomic regions with reduced variation in allele frequency in any population experiencing divergent selection for specific traits. Here, we determined the feasibility of the selective sweep approach for finding genes important for AF deposition in chickens. The long-range haplotype test was employed, which detects selection signature by measuring the characteristics of haplotypes within the lean and fat lines divergently selected for AF content. There were 5357 and 5593 core regions in the lean and fat lines, respectively. When comparing the average marker spacing with mean core length and number of SNPs forming cores, we revealed that core regions are more likely to appear in regions with higher marker density.

The selection signatures on the whole genome were calculated, and a subset of putative core regions with significant REHH $P$-values $(P<0.01)$ was identified. The genes in these core regions were detected and 10 genes, including RB1, BBS7, MAOA, MAOB, EHBP1, LRP2BP, $L R P 1 B, M Y O 7 A, M Y O 9 A$ and PRPSAP1, were important for fatness. Among these 10 important genes, seven genes, including $R B 1, B B S 7, M A O A, M A O B, E H B P 1$, $L R P 2 B P$ and $L R P 1 B$, were all in the QTL regions reported previously for AF in chickens (Table 5). Although the other three genes, including $M Y O 7 A$, 
Table 4 Haplotype frequencies in the lean and fat lines of the core regions including 10 important genes

\begin{tabular}{|c|c|c|c|c|c|}
\hline \multirow[t]{2}{*}{ Gene and core regions } & \multirow[t]{2}{*}{ Haplotype Number } & \multirow[t]{2}{*}{ Haploptypes } & \multicolumn{2}{|c|}{ Haplotype frequency } & \multirow[t]{2}{*}{$P$-value ${ }^{1}$} \\
\hline & & & Lean line & Fat line & \\
\hline$M A O B, M A O A$ & 1 & CAAGG & 0.645 & 0.615 & $<0.001$ \\
\hline \multirow[t]{4}{*}{ Chr1: 114789487-114875623 } & 2 & AAAGA & 0.197 & 0 & \\
\hline & 3 & CGGAG & 0.158 & 0.269 & \\
\hline & 4 & CGAGA & 0 & 0.077 & \\
\hline & 5 & AAAGG & 0 & 0.038 & \\
\hline$R B 1$ & 1 & GGAA & 0.421 & 0.410 & $<0.001$ \\
\hline \multirow[t]{5}{*}{ Chr1: 173098805-173190831 } & 2 & GAGG & 0.368 & 0.103 & \\
\hline & 3 & GAAA & 0.211 & 0.192 & \\
\hline & 4 & AAGG & 0 & 0.244 & \\
\hline & 5 & AGGA & 0 & 0.038 & \\
\hline & 6 & GAGA & 0 & 0.013 & \\
\hline MYO7A & 1 & AGG & 0.618 & 0.090 & $<0.001$ \\
\hline \multirow[t]{4}{*}{ Chr1: 198071099-198113519 } & 2 & GAA & 0.316 & 0.207 & \\
\hline & 3 & GGA & 0.066 & 0.652 & \\
\hline & 4 & GAG & 0 & 0.037 & \\
\hline & 5 & GGG & 0 & 0.014 & \\
\hline EHBP1 & 1 & GGG & 0.855 & 0.090 & $<0.001$ \\
\hline \multirow[t]{3}{*}{ Chr3: 9177907-9222825 } & 2 & GAG & 0.132 & 0.359 & \\
\hline & 3 & AGG & 0.013 & 0.128 & \\
\hline & 4 & GGA & 0 & 0.423 & \\
\hline LRP2BP & 1 & GGGG & 0.443 & 0.487 & $<0.001$ \\
\hline \multirow[t]{3}{*}{ Chr4: 40653593-40713404 } & 2 & AAAA & 0.338 & 0.211 & \\
\hline & 3 & GGAA & 0.176 & 0 & \\
\hline & 4 & AAGG & 0.044 & 0.303 & \\
\hline BBS7 & 1 & AGGC & 0.605 & 0.282 & $<0.001$ \\
\hline \multirow[t]{5}{*}{ Chr4: 55424480-55472209 } & 2 & GAAA & 0.368 & 0.301 & \\
\hline & 3 & AAAA & 0.026 & 0 & \\
\hline & 4 & AGAC & 0 & 0.198 & \\
\hline & 5 & AGAA & 0 & 0.161 & \\
\hline & 6 & GAAC & 0 & 0.058 & \\
\hline LRP1B & 1 & AGAGAC & 0.361 & 0.013 & $<0.001$ \\
\hline \multirow[t]{10}{*}{ Chr7: 33795201-33904515 } & 2 & GGAGGA & 0.197 & & \\
\hline & 3 & AGAAGA & 0.105 & 0.154 & \\
\hline & 4 & GGGGGA & 0.066 & 0.449 & \\
\hline & 5 & AGAAGC & 0.057 & 0.346 & \\
\hline & 6 & GAGGGA & 0.055 & 0.038 & \\
\hline & 7 & GAGAGA & 0.050 & 0 & \\
\hline & 8 & GGAAGA & 0.049 & 0 & \\
\hline & 9 & GAGGAA & 0.026 & 0 & \\
\hline & 10 & GGAGAA & 0.018 & 0 & \\
\hline & 11 & AGAAAC & 0.016 & 0 & \\
\hline MYO9A & 1 & GGGAA & 0.355 & 0.051 & $<0.001$ \\
\hline \multirow[t]{4}{*}{ Chr10: 763998-831991 } & 2 & AAGAA & 0.276 & 0.358 & \\
\hline & 3 & AAGAG & 0.237 & 0 & \\
\hline & 4 & GGGGA & 0.118 & 0.013 & \\
\hline & 5 & AGGAA & 0.013 & 0.065 & \\
\hline
\end{tabular}


Table 4 Haplotype frequencies in the lean and fat lines of the core regions including 10 important genes (Continued)

\begin{tabular}{llllll}
\hline & 6 & AGAAA & 0 & $\mathbf{0 . 5 0 0}$ \\
\cline { 2 - 5 } & & 7 & AAAAA & 0 & 0.013 \\
\hline PRPSAP1 & 1 & AGA & 0.816 & 0.615 & $<0.001$ \\
\cline { 3 - 5 } & 2 & GGG & $\mathbf{0 . 1 1 8}$ & 0.026 \\
\cline { 2 - 5 }
\end{tabular}

${ }^{1} P$-values of Fisher's Exact Test for difference analysis of haplotype frequencies between lean and fat lines.

MYO9A and PRPSAP1, were not in the QTL regions, these genes were also important for the AF deposition.

The known functions of these 10 genes were analyzed and the results indicated that they were likely to be linked with fatness. The RB1 gene regulates the C/EBPDNA-binding activity during 3T3-L1 adipogenesis and plays a key role in adipocyte differentiation $[40,41]$.

The $B B S 7$ gene is a member of the Bardet-Biedl syndrome (BBS) family. BBS is a pleiotropic genetic disorder characterized by obesity, photoreceptor degeneration, polydactyly, hypogenitalism, renal abnormalities, and developmental delay [42]. BBS is recognized to be a genetically heterogeneous autosomal recessive disorder mapped to eight loci [42]. Positional cloning and candidate genes identified six BBS genes, including $B B S 1, B B S 2, B B S 4$, $B B S 6, B B S 7$, and $B B S 8$ [42]. These BBS genes may be important for obesity.

The $M A O A$ and $M A O B$ are two enzymes important for dopamine production. The dopamine levels influence the risk of obesity and $M A O A$ and $M O A B$ may be implicated in human obesity [43].

The EHBP1 gene is required for insulin-stimulated GLUT4 movements [44]. Insulin stimulates glucose transport in adipose tissues by recruiting intracellular membrane vesicles containing the glucose transporter GLUT4 to the plasma membrane [44]. The mechanisms involved in the biogenesis of these vesicles and their translocation to the cell surface were studied and the results indicated that EHD1 and EHBP1 are required for perinuclear localization of GLUT4, and the loss of EHBP1 disrupts insulin-regulated GLUT4 recycling in cultured adipocytes [44]. This indicates that the EHBP1 gene may be important in adipocyte differentiation.

The $L R P 2 B P$ and $L R P 1 B$ genes are two members of the low-density lipoprotein receptor family that participates in a wide range of physiological processes, including the regulation of lipid metabolism, protection against atherosclerosis, neurodevelopment, and transport of nutrients and vitamins [45].

The MYO7A and MYO9A are two myosin genes. A spontaneous mutant mouse line, Myo $7^{\text {ash1-6J }}$, was used to study the function of the MYO7A gene, and the result indicated that the mutant male homozygous mice displayed decreased body weight and body fat [46].
The MYO9A gene was in the BBS4 region of chromosome 15q22-q23 [47], which might be important for obesity.

The PRPSAP1 gene is named as phosphoribosyl pyrophosphate synthetase-associated protein 1 . The results of differentially expressed genes associated with insulin resistance indicate that PRPSAP1 gene is associated with percentage of body fat [48].

The associations of these 10 genes with obesity or lipid metabolism were mainly in humans and mice. Because of the high conservation of these genes between humans, mice and chickens, the 10 genes might also be important for AF deposition in chickens.

\section{Conclusions}

Our results provide a genome-wide map of selection signatures in two chicken lines divergently selected for $\mathrm{AF}$ content. There were 51 and 57 core regions showing significant $P$-values $(P<0.01)$ of selection signatures in the lean and fat lines, respectively. In these core regions there were a number of important genes, including $R B 1$, BBS7, MAOA, MAOB, EHBP1, LRP2BP, LRP1B, MYO7A, MYO9A and PRPSAP1. These genes are important for AF deposition in chickens.

\section{Abbreviations}

AF: Abdominal fat; AFP: Abdominal fat percentage; AFW: Abdominal fat weight; BBS: Bardet-Biedl syndrome; CH: Core haplotypes; CR: Core region; EHH: Extended haplotype homozygosity; IHS: Integrated Haplotype Score; LD: Linkage disequilibrium; NEAU: Northeast Agricultural University; NEAUHLF: Northeast Agricultural University broiler lines divergently selected for abdominal fat content; NRC: National Research Council; QTL: Quantitative trait loci; REHH: Relative Extended Haplotype Homozygosity; SNP: Single nucleotide polymorphism; VLDL: Very low-density lipoprotein.

\section{Competing interests}

There are no potential competing interests related to this manuscript.

\section{Authors' contributions}

$\mathrm{HZ}$ contributed to, conceived and designed the experiments, participated in the interpretation of the data, and drafted and wrote the manuscript. SZW participated in the design of the study and interpretation of the data, and contributed to writing the manuscript. ZPW participated in the design of the study and contributed to writing the manuscript. YD carried out analysis and interpretation of the data. NW participated in the design of the study and contributed to the analysis of the data. XXH participated in the analysis and interpretation of the data. YDZ participated in the design of the study and contributed to the analysis of the data. YXW participated in the design of the study. LL contributed reagents/materials/analysis tools. ZQT contributed reagents/materials/analysis tools. $\mathrm{HL}$ co-led the conception and design of 
Table 5 Reported QTL near the core regions with $P<0.01$ in the lean and fat lines

\begin{tabular}{|c|c|c|c|c|c|c|}
\hline \multicolumn{7}{|c|}{ Lean line } \\
\hline Chr & Core region (bp) & Trait & QTL position (bp) & F-ratio & $P$-value & Reference \\
\hline 1 & $39360501-39455853$ & AFP & $1937738-52700434$ & 1.474 & Suggestive & [21] \\
\hline \multirow[t]{3}{*}{1} & $49926970-49964278$ & AFP & 25998723-65961966 & 1.732 & Suggestive & [21] \\
\hline & & AFW & 25998723-65961966 & 1.882 & Suggestive & {$[21]$} \\
\hline & & AFW & $48175152-51977642$ & 8.14 & Significant & [22] \\
\hline \multirow[t]{2}{*}{1} & $173098805-173190831$ & AFW & $158352237-182910620$ & 3.18 & Significant & {$[23]$} \\
\hline & & AFP & $171224834-174526878$ & 20.34 & Significant & [23] \\
\hline 2 & 3631683-3739002 & AFW & $3097660-4097660$ & 3.38 & Suggestive & [24] \\
\hline 3 & 3794973-3861882 & AFP & 800029-110574691 & 1.364 & Suggestive & [21] \\
\hline \multirow[t]{4}{*}{3} & $10257926-10454969$ & AFP & 800029-110574691 & 1.364 & Suggestive & {$[21]$} \\
\hline & & AFW & 6841859-13986734 & 8.16 & Significant & {$[22]$} \\
\hline & & AFP & 6841859- 57396057 & 7.9 & Significant & {$[25]$} \\
\hline & & AFW & 6841859- 44850897 & 7.4 & Significant & {$[25]$} \\
\hline \multirow[t]{5}{*}{3} & $14895290-14957057$ & AFP & 800029-110574691 & 1.364 & Suggestive & [21] \\
\hline & & AFW & 6841859-13986734 & 8.16 & Significant & {$[22]$} \\
\hline & & AFP & 6841859- 57396057 & 7.9 & Significant & {$[25]$} \\
\hline & & AFW & 6841859- 44850897 & 7.4 & Significant & {$[25]$} \\
\hline & & AFW & 13986734-25508863 & 1 & Suggestive & {$[26]$} \\
\hline \multirow[t]{5}{*}{3} & 26957549-26996618 & AFP & 800029-110574691 & 1.364 & Suggestive & {$[21]$} \\
\hline & & AFP & 6841859- 57396057 & 7.9 & Significant & {$[25]$} \\
\hline & & AFW & 6841859- 44850897 & 7.4 & Significant & {$[25]$} \\
\hline & & AFW & $24160710-51592221$ & 1 & Suggestive & {$[27]$} \\
\hline & & AFW & $25508863-35512024$ & 1 & Suggestive & {$[26]$} \\
\hline \multirow[t]{5}{*}{3} & $27303800-27335510$ & AFP & 800029-110574691 & 1.364 & Suggestive & [21] \\
\hline & & AFP & 6841859- 57396057 & 7.9 & Significant & {$[25]$} \\
\hline & & AFW & 6841859- 44850897 & 7.4 & Significant & {$[25]$} \\
\hline & & AFW & $24160710-51592221$ & 1 & Suggestive & {$[27]$} \\
\hline & & AFW & $25508863-35512024$ & 1 & Suggestive & {$[26]$} \\
\hline \multirow[t]{5}{*}{3} & 27382993-27430067 & AFP & 800029-110574691 & 1.364 & Suggestive & [21] \\
\hline & & AFP & 6841859- 57396057 & 7.9 & Significant & {$[25]$} \\
\hline & & AFW & 6841859- 44850897 & 7.4 & Significant & {$[25]$} \\
\hline & & AFW & $24160710-51592221$ & 1 & Suggestive & {$[27]$} \\
\hline & & AFW & $25508863-35512024$ & 1 & Suggestive & {$[26]$} \\
\hline \multirow[t]{3}{*}{3} & $35555718-35610466$ & AFP & 800029-110574691 & 1.364 & Suggestive & [21] \\
\hline & & AFW & $35512024-40755790$ & 18.5 & Significant & {$[28]$} \\
\hline & & AFP & $35512024-40755790$ & 13.1 & Significant & {$[28]$} \\
\hline 4 & $17765695-17819334$ & AFW & $17425871-18425871$ & 1 & Significant & {$[29]$} \\
\hline 4 & $46149116-46190279$ & AFW & $42005559-51609571$ & 2.26 & Suggestive & {$[30]$} \\
\hline 4 & $55424480-55472209$ & AFP & 51266614- 88408499 & 16.0 & Significant & {$[25]$} \\
\hline \multirow[t]{3}{*}{4} & $83051637-83117974$ & AFP & 51266614- 88408499 & 16.0 & Significant & {$[25]$} \\
\hline & & AFW & 80258156-88408499 & 6.9 & Significant & {$[25]$} \\
\hline & & AFW & $81539616-84618310$ & 2.04 & Suggestive & [30] \\
\hline \multirow[t]{4}{*}{5} & $23825115-23872187$ & AFW & $18412554-42717839$ & 21.8 & Significant & {$[25]$} \\
\hline & & AFP & 18723157- 43339045 & 19.4 & Significant & {$[25]$} \\
\hline & & AFW & $19782191-30162990$ & 1 & Suggestive & {$[26]$} \\
\hline & & AFW & $19782191-30162990$ & 7.04 & Significant & {$[31]$} \\
\hline
\end{tabular}


Table 5 Reported QTL near the core regions with $\boldsymbol{P}<\mathbf{0 . 0 1}$ in the lean and fat lines (Continued)

\begin{tabular}{|c|c|c|c|c|c|c|}
\hline \multirow[t]{3}{*}{5} & \multirow[t]{3}{*}{$42592517-42679460$} & AFW & $18412554-42717839$ & 21.8 & Significant & [25] \\
\hline & & AFP & 18723157- 43339045 & 19.4 & Significant & [25] \\
\hline & & AFW & $37226264-53779276$ & 6.74 & Significant & [31] \\
\hline 6 & $35354459-35390346$ & AFP & $29647151-37399694$ & 6.9 & Significant & [25] \\
\hline \multirow[t]{3}{*}{7} & \multirow[t]{3}{*}{$28869664-28906344$} & AFW & $25306930-38010856$ & 1 & Suggestive & [27] \\
\hline & & AFW & $28166221-29166221$ & 9.78 & Significant & [32] \\
\hline & & $\overline{A F W}$ & $28166221-29166221$ & 1 & Significant & [33] \\
\hline 7 & $35674098-35715122$ & AFW & $25306930-38010856$ & 1 & Suggestive & [27] \\
\hline \multirow[t]{2}{*}{9} & \multirow[t]{2}{*}{$16264832-16366749$} & AFW & $13658592-23770679$ & 5.03 & Suggestive & [22] \\
\hline & & AFW & $15457880-16457880$ & 7.0 & Suggestive & [34] \\
\hline 10 & 19717086-19745274 & AFP & 16519830- 20778533 & 9.9 & Significant & [28] \\
\hline 13 & $16758621-16783127$ & AFW & 16327806- 18173123 & 2.10 & Suggestive & [30] \\
\hline \multirow[t]{6}{*}{15} & \multirow[t]{6}{*}{ 7345639-7377799 } & AFW & $1917251-10769106$ & 10.2 & Significant & {$[25]$} \\
\hline & & $\overline{A F P}$ & $2388961-10769106$ & 12.8 & Significant & {$[25]$} \\
\hline & & AFW & 2798507-10769106 & 8.13 & Significant & [22] \\
\hline & & $\overline{A F W}$ & $2798507-10769106$ & 5.67 & Suggestive & [22] \\
\hline & & AFW & $3717446-7928397$ & 2.21 & Suggestive & [30] \\
\hline & & AFP & $3717446-7928397$ & 2.22 & Suggestive & [30] \\
\hline \multicolumn{7}{|c|}{ Fat line } \\
\hline \multirow[t]{4}{*}{1} & \multirow[t]{4}{*}{$51248496-51279543$} & AFP & 1937738-52700434 & 1.474 & Suggestive & [21] \\
\hline & & AFW & $48175152-51977642$ & 8.14 & Significant & [22] \\
\hline & & AFP & 25998723- 65961966 & 1.732 & Suggestive & [21] \\
\hline & & $\overline{A F W}$ & $25998723-65961966$ & 1.882 & Suggestive & {$[21]$} \\
\hline \multirow[t]{3}{*}{1} & \multirow[t]{3}{*}{$58120009-58215364$} & AFP & $25998723-65961966$ & 1.732 & Suggestive & [21] \\
\hline & & AFW & $25998723-65961966$ & 1.882 & Suggestive & [21] \\
\hline & & AFW & $55261695-67128747$ & 12.18 & Significant & [35] \\
\hline \multirow[t]{3}{*}{1} & \multirow[t]{3}{*}{$60171076-60254771$} & AFP & 25998723- 65961966 & 1.732 & Suggestive & [21] \\
\hline & & AFW & $25998723-65961966$ & 1.882 & Suggestive & [21] \\
\hline & & AFW & $55261695-67128747$ & 12.18 & Significant & [35] \\
\hline 1 & $67763862-67830818$ & AFW & $67327367-68327367$ & 1 & Significant & [33] \\
\hline 1 & $68213617-68257241$ & AFW & $67327367-68327367$ & 1 & Significant & [33] \\
\hline \multirow[t]{2}{*}{1} & \multirow[t]{2}{*}{$101535615-101635667$} & AFW & 89938943-167462479 & 9.4 & Significant & [36] \\
\hline & & AFW & 94157976- 102460326 & 6.11 & Suggestive & [35] \\
\hline \multirow[t]{2}{*}{1} & \multirow[t]{2}{*}{$114789487-114875623$} & AFW & $113344161-132660888$ & 7.90 & Suggestive & [35] \\
\hline & & $\overline{A F W}$ & 114143603- 115143603 & 7.1 & Significant & [36] \\
\hline 1 & $125909995-126011984$ & AFW & $113344161-132660888$ & 7.90 & Suggestive & [35] \\
\hline 1 & $181800227-181883545$ & AFW & $158352237-182910620$ & 3.18 & Significant & [23] \\
\hline \multirow[t]{5}{*}{3} & \multirow[t]{5}{*}{$9177907-9222825$} & AFP & $800029-110574691$ & 1.364 & Suggestive & [21] \\
\hline & & AFW & 6841859- 13986734 & 8.16 & Significant & [22] \\
\hline & & AFW & 6841859- 13986734 & 5.8 & Suggestive & [22] \\
\hline & & AFP & $6841859-57396057$ & 7.9 & Significant & [25] \\
\hline & & AFW & $6841859-44850897$ & 7.4 & Significant & {$[25]$} \\
\hline \multirow[t]{4}{*}{3} & \multirow[t]{4}{*}{$16143474-16194865$} & AFP & $800029-110574691$ & 1.364 & Suggestive & [21] \\
\hline & & AFP & $6841859-57396057$ & 7.9 & Significant & {$[25]$} \\
\hline & & $\overline{A F W}$ & $6841859-44850897$ & 7.4 & Significant & {$[25]$} \\
\hline & & $\overline{A F W}$ & $13986734-25508863$ & 1 & Suggestive & {$[26]$} \\
\hline
\end{tabular}


Table 5 Reported QTL near the core regions with $\mathbf{P}<\mathbf{0 . 0 1}$ in the lean and fat lines (Continued)

\begin{tabular}{|c|c|c|c|c|c|c|}
\hline \multirow[t]{5}{*}{3} & \multirow[t]{5}{*}{ 24945839-24986772 } & AFP & 800029- 110574691 & 1.364 & Suggestive & [21] \\
\hline & & AFP & $6841859-57396057$ & 7.9 & Significant & {$[25]$} \\
\hline & & AFW & 6841859-44850897 & 7.4 & Significant & [25] \\
\hline & & AFW & 13986734-25508863 & 1 & Suggestive & [26] \\
\hline & & AFW & $24160710-51592221$ & 1 & Suggestive & {$[27]$} \\
\hline \multirow[t]{6}{*}{3} & \multirow[t]{6}{*}{$44265116-44311493$} & AFP & 800029- 110574691 & 1.364 & Suggestive & [21] \\
\hline & & AFP & $6841859-57396057$ & 7.9 & Significant & {$[25]$} \\
\hline & & AFW & 6841859-44850897 & 7.4 & Significant & [25] \\
\hline & & AFW & $24160710-51592221$ & 1 & Suggestive & {$[27]$} \\
\hline & & AFW & $40755790-45203763$ & 7.5 & Significant & [28] \\
\hline & & AFP & $40755790-45203763$ & 10.8 & Significant & [28] \\
\hline 3 & 69863850-69906698 & AFP & 800029- 110574691 & 1.364 & Suggestive & [21] \\
\hline 3 & 85874137-85931473 & AFP & 800029- 110574691 & 1.364 & Suggestive & [21] \\
\hline 3 & 97227680-97337906 & AFP & $800029-110574691$ & 1.364 & Suggestive & [21] \\
\hline 4 & 40653593-40713404 & AFP & $40473174-41473174$ & 1 & Significant & [32] \\
\hline 4 & 55950677-55991394 & AFP & 51266614- 88408499 & 16.0 & Significant & {$[25]$} \\
\hline \multirow[t]{2}{*}{4} & \multirow[t]{2}{*}{ 86719441-86754976 } & AFP & 51266614- 88408499 & 16.0 & Significant & {$[25]$} \\
\hline & & AFW & 80258156-88408499 & 6.9 & Significant & [25] \\
\hline \multirow[t]{6}{*}{5} & \multirow[t]{6}{*}{$40239840-40261525$} & AFW & 18412554- 42717839 & 21.8 & Significant & [25] \\
\hline & & AFP & 18723157- 43339045 & 19.4 & Significant & [25] \\
\hline & & AFW & 37226264- 53779276 & 6.74 & Significant & [31] \\
\hline & & AFW & 40158255- 41158255 & 1 & Significant & [37] \\
\hline & & AFW & $40158255-41158255$ & 1 & Significant & [38] \\
\hline & & AFP & $40158255-41158255$ & 1 & Significant & [38] \\
\hline 5 & $47240577-47282933$ & AFW & 37226264- 53779276 & 6.74 & Significant & [31] \\
\hline \multirow[t]{3}{*}{5} & \multirow[t]{3}{*}{ 59811459-59880511 } & AFW & $51748760-60234891$ & 1 & Significant & [26] \\
\hline & & AFW & 53867807-62098509 & 11.87 & Significant & [31] \\
\hline & & AFW & 53867807-62098509 & 6.82 & Significant & [31] \\
\hline 7 & $30090927-30155133$ & AFW & 25306930- 38010856 & 1 & Suggestive & {$[27]$} \\
\hline 7 & $31374271-31418061$ & AFW & 25306930- 38010856 & 1 & Suggestive & {$[27]$} \\
\hline \multirow[t]{2}{*}{7} & \multirow[t]{2}{*}{$33795201-33904515$} & AFW & 25306930- 38010856 & 1 & Suggestive & {$[27]$} \\
\hline & & AFW & $32440861-34526547$ & 2.08 & Suggestive & [30] \\
\hline 7 & $36818722-36875768$ & AFW & 25306930- 38010856 & 1 & Suggestive & {$[27]$} \\
\hline 7 & $37031922-37124566$ & AFW & 25306930- 38010856 & 1 & Suggestive & {$[27]$} \\
\hline \multirow[t]{2}{*}{9} & \multirow[t]{2}{*}{ 2952291-3007034 } & AFW & 2798942-3798942 & 1 & Significant & [32] \\
\hline & & AFP & 2972071-3972071 & 1 & Significant & {$[32]$} \\
\hline 11 & 9804894-9826761 & AFW & $6272742-12810705$ & 2.15 & Suggestive & [30] \\
\hline \multirow[t]{3}{*}{12} & \multirow[t]{3}{*}{ 1157199-1170169 } & AFP & 734209- 12275026 & 5.22 & Significant & {$[28]$} \\
\hline & & AFP & 734209- 12275026 & 4.51 & Significant & [28] \\
\hline & & AFP & 813709-1813709 & 1 & Significant & {$[32]$} \\
\hline \multirow[t]{4}{*}{15} & \multirow[t]{4}{*}{ 8495796-8543001 } & AFW & 1917251- 10769106 & 10.2 & Significant & {$[25]$} \\
\hline & & AFP & 2388961- 10769106 & 12.8 & Significant & [25] \\
\hline & & AFW & 2798507- 10769106 & 8.13 & Significant & {$[22]$} \\
\hline & & AFW & 2798507- 10769106 & 5.67 & Suggestive & {$[22]$} \\
\hline 23 & $935267-970086$ & AFW & 74802-1074802 & 1 & Significant & [39] \\
\hline
\end{tabular}


the study, participated in the interpretation of the data, and contributed to writing the manuscript. All authors submitted comments on drafts, and read and approved the final manuscript.

\section{Acknowledgements}

The authors would like to acknowledge the members of the Poultry Breeding Group of the College of Animal Science and Technology in Northeast Agricultural University for managing the birds and collecting data. This research was supported by the China Agriculture Research System (No. CARS-42), National 863 Project of China (No. 2011AA100301), National 973 Project of China (No. 2009CB941604) and Program for Innovation Research Team in University of Heilongjiang Province (No. 2010td02).

\section{Author details}

${ }^{1}$ Key Laboratory of Chicken Genetics and Breeding, Ministry of Agriculture Harbin 150030, P.R. China. ${ }^{2}$ College of Animal Science and Technology, Northeast Agricultural University, Harbin 150030, P.R. China. ${ }^{3}$ Department of Animal Science, University of Minnesota, Saint Paul, Minnesota 55108, USA. ${ }^{4}$ College of Biological Science, China Agricultural University, Beijing 100193, P.R. China. ${ }^{5}$ Animal Genetics and Breeding Unit, University of New England, Armidale, New South Wales 2351, Australia.

Received: 3 September 2012 Accepted: 10 December 2012 Published: 15 December 2012

\section{References}

1. Meuwissen TH, Hayes BJ, Goddard ME: Prediction of total genetic value using genome-wide dense marker maps. Genetics 2001, 157(4):1819-1829.

2. Pollinger JP, Bustamante CD, Fledel-Alon A, Schmutz S, Gray MM, Wayne RK: Selective sweep mapping of genes with large phenotypic effects. Genome Res 2005, 15(12):1809-1819.

3. Daetwyler HD, Schenkel FS, Sargolzaei M, Robinson JA: A genome scan to detect quantitative trait loci for economically important traits in Holstein cattle using two methods and a dense single nucleotide polymorphism map. J Dairy Sci 2008, 91(8):3225-3236.

4. Hayes BJ, Lien S, Nilsen H, Olsen HG, Berg P, Maceachern S, Potter S, Meuwissen $\mathrm{TH}$ : The origin of selection signatures on bovine chromosome 6. Anim Genet 2008, 39(2):105-111.

5. Hayes BJ, Chamberlain AJ, Maceachern S, Savin K, McPartlan H, MacLeod I, Sethuraman L, Goddard ME: A genome map of divergent artificial selection between Bos taurus dairy cattle and Bos taurus beef cattle. Anim Genet 2009, 40(2):176-184.

6. Prasad A, Schnabel RD, McKay SD, Murdoch B, Stothard P, Kolbehdari D, Wang Z, Taylor JF, Moore SS: Linkage disequilibrium and signatures of selection on chromosomes 19 and 29 in beef and dairy cattle. Anim Genet 2008, 39(6):597-605.

7. Qanbari S, Pimentel EC, Tetens J, Thaller G, Lichtner P, Sharifi AR, Simianer $\mathrm{H}$ : A genome-wide scan for signatures of recent selection in Holstein cattle. Anim Genet 2010, 41(4):377-389.

8. Kimura M: The Neutral Theory of Molecular Evolution. Cambridge, MA: Cambridge University Press; 1983.

9. Smith JM, Haigh J: The hitch-hiking effect of a favourable gene. Genet Res 1974, 23(1):23-35.

10. Nielsen R: Molecular signatures of natural selection. Annu Rev Genet 2005, 39:197-218.

11. Sabeti PC, Reich DE, Higgins JM, Levine HZ, Richter DJ, Schaffner SF, Gabriel SB, Platko JV, Patterson NJ, McDonald GJ, Ackerman HC, Campbell SJ, Altshuler D, Cooper R, Kwiatkowski D, Ward R, Lander ES: Detecting recent positive selection in the human genome from haplotype structure. Nature 2002, 419(6909):832-837.

12. Tajima F: Statistical method for testing the neutral mutation hypothesis by DNA polymorphism. Genetics 1989, 123(3):585-595.

13. Fay JC, Wu Cl: Hitchhiking under positive Darwinian selection. Genetics 2000, 155(3):1405-1413.

14. Akey JM, Zhang G, Zhang K, Jin L, Shriver MD: Interrogating a high-density SNP map for signatures of natural selection. Genome Res 2002, 12(12):1805-1814.

15. Voight BF, Kudaravalli S, Wen X, Pritchard JK: A map of recent positive selection in the human genome. PLoS Biol 2006, 4(3):e72.
16. Tang K, Thornton KR, Stoneking M: A new approach for using genome scans to detect recent positive selection in the human genome. PLoS Biol 2007, 5(7):e171.

17. Guo L, Sun B, Shang Z, Leng L, Wang Y, Wang N, Li H: Comparison of adipose tissue cellularity in chicken lines divergently selected for fatness. Poult Sci 2011, 90(9):2024-2034

18. Scheet $P$, Stephens M: A fast and flexible statistical model for large-scale population genotype data: applications to inferring missing genotypes and haplotypic phase. Am J Hum Genet 2006, 78(4):629-644.

19. Barrett JC, Fry B, Maller J, Daly MJ: Haploview: analysis and visualization of LD and haplotype maps. Bioinformatics 2005, 21(2):263-265.

20. Gabriel SB, Schaffner SF, Nguyen H, Moore JM, Roy J, Blumenstiel B, Higgins J, DeFelice M, Lochner A, Faggart M, Liu-Cordero SN, Rotimi C, Adeyemo A, Cooper R, Ward R, Lander ES, Daly MJ, Altshuler D: The structure of haplotype blocks in the human genome. Science 2002, 296(5576):2225-2229.

21. Jennen DG, Vereijken AL, Bovenhuis $H$, Crooijmans RM, van der Poel Jر, Groenen MA: Confirmation of quantitative trait loci affecting fatness in chickens. Genet Sel Evol 2005, 37(2):215-228.

22. Ikeobi CO, Woolliams JA, Morrice DR, Law A, Windsor D, Burt DW, Hocking PM: Quantitative trait loci affecting fatness in the chicken. Anim Genet 2002, 33(6):428-435.

23. Liu X, Zhang H, Li H, Li N, Zhang Y, Zhang Q, Wang S, Wang Q, Wang H: Fine-mapping quantitative trait loci for body weight and abdominal fat traits: effects of marker density and sample size. Poult Sci 2008, 87(7):1314-1319.

24. McElroy JP, Kim JJ, Harry DE, Brown SR, Dekkers JC, Lamont SJ: Identification of trait loci affecting white meat percentage and other growth and carcass traits in commercial broiler chickens. Poult Sci 2006, 85(4):593-605.

25. Nadaf J, Pitel F, Gilbert H, Duclos MJ, Vignoles F, Beaumont C, Vignal A Porter TE, Cogburn LA, Aggrey SE, Simon J, Le Bihan-Duval E: QTL for several metabolic traits map to loci controlling growth and body composition in an F2 intercross between high- and low-growth chicken lines. Physiol Genomics 2009, 38(3):241-249.

26. Lagarrique S, Pitel F, Carré W, Abasht B, Le Roy P, Neau A, Amigues Y, Sourdioux M, Simon J, Cogburn L, Aggrey S, Leclercq B, Vignal A, Douaire M: Mapping quantitative trait loci affecting fatness and breast muscle weight in meat-type chicken lines divergently selected on abdominal fatness. Genet Sel Evol 2006, 38(1):85-97.

27. Park HB, Jacobsson L, Wahlberg P, Siegel PB, Andersson L: QTL analysis of body composition and metabolic traits in an intercross between chicken lines divergently selected for growth. Physiol Genomics 2006, 25(2):216-223.

28. Campos RL, Nones K, Ledur MC, Moura AS, Pinto LF, Ambo M, Boschiero C, Ruy DC, Baron EE, Ninov K, Altenhofen CA, Silva RA, Rosário MF, Burt DW Coutinho LL: Quantitative trait loci associated with fatness in a broiler-layer cross. Anim Genet 2009, 40(5):729-736.

29. Atzmon G, Blum S, Feldman M, Lavi U, Hillel J: Detection of agriculturally important QTLs in chickens and analysis of the factors affecting genotyping strategy. Cytogenet Genome Res 2007, 117(1-4):327-337

30. Jennen DG, Vereijken AL, Bovenhuis H, Crooijmans RP, Veenendaal A, van der Poel JJ, Groenen MA: Detection and localization of quantitative trait loci affecting fatness in broilers. Poult Sci 2004, 83(3):295-301.

31. Abasht B, Pitel F, Lagarrigue S, Le Bihan-Duval E, Le Roy P, Demeure O, Vignoles F, Simon J, Cogburn L, Aggrey S, Vignal A, Douaire M: Fatness QTL on chicken chromosome 5 and interaction with sex. Genet Sel Evol 2006, 38(3):297-311

32. Ankra-Badu GA, Shriner D, Le Bihan-Duval E, Mignon-Grasteau S, Pitel F, Beaumont C, Duclos MJ, Simon J, Porter TE, Vignal A, Cogburn LA, Allison DB, Yi N, Aggrey SE: Mapping main, epistatic and sex-specific QTL for body composition in a chicken population divergently selected for low or high growth rate. BMC Genomics 2010, 11:107.

33. Atzmon G, Blum S, Feldman M, Cahaner A, Lavi U, Hillel J: QTLs detected in a multigenerational resource chicken population. J Hered 2008, 99(5):528-538

34. Zhou H, Deeb N, Evock-Clover CM, Ashwell CM, Lamont SJ: Genome-wide linkage analysis to identify chromosomal regions affecting phenotypic traits in the chicken. II. Body composition. Poult Sci 2006, 85(10):1712-1721. 
35. Nones K, Ledur MC, Ruy DC, Baron EE, Melo CM, Moura AS, Zanella EL, Burt DW, Coutinho LL: Mapping QTLs on chicken chromosome 1 for performance and carcass traits in a broiler x layer cross. Anim Genet 2006, 37(2):95-100.

36. Uemoto Y, Sato S, Odawara S, Nokata H, Oyamada Y, Taguchi Y, Yanai S, Sasaki O, Takahashi H, Nirasawa K, Kobayashi E: Genetic mapping of quantitative trait loci affecting growth and carcass traits in F2 intercross chickens. Poult Sci 2009, 88(3):477-482.

37. Le Mignon G, Pitel F, Gilbert H, Le Bihan-Duval E, Vignoles F, Demeure O, Lagarrigue S, Simon J, Cogburn LA, Aggrey SE, Douaire M, Le Roy P: A comprehensive analysis of QTL for abdominal fat and breast muscle weights on chicken chromosome 5 using a multivariate approach. Anim Genet 2009, 40(2):157-164.

38. Li H, Deeb N, Zhou H, Mitchell AD, Ashwell CM, Lamont SJ: Chicken quantitative trait loci for growth and body composition associated with transforming growth factor-beta genes. Poult Sci 2003, 82(3):347-356.

39. Hu G, Wang SZ, Wang ZP, Li YM, Li H: Genetic epistasis analysis of 10 peroxisome proliferator-activated receptor $\gamma$-correlated genes in broiler lines divergently selected for abdominal fat content. Poult Sci 2010, 89(11):2341-2350.

40. Fajas L, Egler V, Reiter R, Hansen J, Kristiansen K, Debril MB, Miard S, Auwerx J: The retinoblastoma-histone deacetylase 3 complex inhibits PPARgamma and adipocyte differentiation. Dev Cell 2002, 3(6):903-910

41. Cole KA, Harmon AW, Harp JB, Patel YM: Rb regulates C/EBPbeta-DNAbinding activity during 3T3-L1 adipogenesis. Am J Physio/ Cell Physiol 2004, 286(2):C349-C354.

42. Sheffield VC: Use of isolated populations in the study of a human obesity syndrome, the Bardet-Biedl syndrome. Pediatr Res 2004, 55(6):908-911.

43. Need AC, Ahmadi KR, Spector TD, Goldstein DB: Obesity is associated with genetic variants that alter dopamine availability. Ann Hum Genet 2006, 70(Pt 3):293-303.

44. Guilherme A, Soriano NA, Furcinitti PS, Czech MP: Role of EHD1 and EHBP1 in perinuclear sorting and insulin-regulated GLUT4 recycling in 3T3-L1 adipocytes. J Biol Chem 2004, 279(38):40062-40075.

45. May P, Woldt E, Matz RL, Boucher P: The LDL receptor-related protein (LRP) family: an old family of proteins with new physiological functions. Ann Med 2007, 39(3):219-228.

46. Gibson F, Walsh J, Mburu P, Varela A, Brown KA, Antonio M, Beisel KW, Steel KP, Brown SD: A type VII myosin encoded by the mouse deafness gene shaker-1. Nature 1995, 374(6517):62-64.

47. Gorman SW, Haider NB, Grieshammer U, Swiderski RE, Kim E, Welch JW, Searby C, Leng S, Carmi R, Sheffield VC, Duhl DM: The cloning and developmental expression of unconventional myosin IXA (MYO9A) a gene in the Bardet-Biedl syndrome (BBS4) region at chromosome 15q22-q23. Genomics 1999, 59(2):150-160.

48. Lee YH, Tokraks S, Pratley RE, Bogardus C, Permana PA: Identification of differentially expressed genes in skeletal muscle of non-diabetic insulin-resistant and insulin-sensitive Pima Indians by differential display PCR. Diabetologia 2003, 46(11):1567-1575.

doi:10.1186/1471-2164-13-704

Cite this article as: Zhang et al: A genome-wide scan of selective sweeps in two broiler chicken lines divergently selected for abdominal fat content. BMC Genomics 2012 13:704.

\section{Submit your next manuscript to BioMed Central and take full advantage of:}

- Convenient online submission

- Thorough peer review

- No space constraints or color figure charges

- Immediate publication on acceptance

- Inclusion in PubMed, CAS, Scopus and Google Scholar

- Research which is freely available for redistribution

Submit your manuscript at www.biomedcentral.com/submit
Ciomed Central 